\title{
MRI findings of penile paraffinoma
}

\author{
Sharifah Majedah, ${ }^{1}$ Mohammad Hanafiah, ${ }^{2}$ Mohd Khairul Awang ${ }^{1}$
}

'Department of Radiology, University Kebangsaan Malaysia Medical Centre, Cheras, Kuala Lumpur, Malaysia

${ }^{2}$ Medical Imaging Unit, Universiti Teknologi MARA, Sungai Buloh, Selangor, Malaysia

\section{Correspondence to} Dr Mohammad Hanafiah, mhanafiah8804@gmail.com

Accepted 2 November 2014

\section{DESCRIPTION}

We demonstrate the MRI of a penis of a 36-year-old man who presented with a 3-week history of progressive penile swelling and reduced stream of passing urine. He claimed to have undergone penile subcutaneous tissue paraffin injection 4 years prior to this presentation, which was performed by an untrained person for augmentation of penile size and contour. Clinically, there was a diffuse nodular enlargement of the penis. The urine microscopy analysis was normal. There were no clinical signs or biochemical evidence of urinary tract infection.

MRI of the penis showed circumferential and diffuse thickening of the space between the Buck's fascia and the skin overlying the penis. It involved the whole of the penile shaft, compatible with previous sites of injection. It was hyposignal on T1-weighted (T1W) and T2W sequences (figure 1). The postgadolinium T1W images showed minimal heterogeneous enhancement of the lesions. The patient underwent excision of the lesions followed by reconstructive surgery. The histopathological analysis of these lesions confirmed the final diagnosis of sclerosing lipogranuloma. His poor urine stream, which is an unusual presentation of this entity, also improved after the surgery.

Liquid paraffin is a colourless, almost odourless, highly refined mineral oil composed of saturated hydrocarbons obtained from petroleum. ${ }^{1}$ Penile paraffinoma is an uncommon entity produced by paraffin injection for the purpose of penile augmentation. The body's lack of enzymes to metabolise interstitial exogenous oils coupled with granulomatous foreign body reaction and fibrosis leads to paraffinoma formation. ${ }^{2}$

In general, the MRI signals for paraffinoma are variable depending on the time between the injections and the scanning. Recent instillation of mineral oil normally demonstrates a high signal in T1W due to its inherent MR property of short T1 relaxation time. The signal gradually changes as the granulomatous inflammatory reactions and fibrosis take place. Although it is a rare entity, clinicians should be aware of this procedure, which is still popular in some parts of the world, such as Asia and Eastern European countries despite its severe

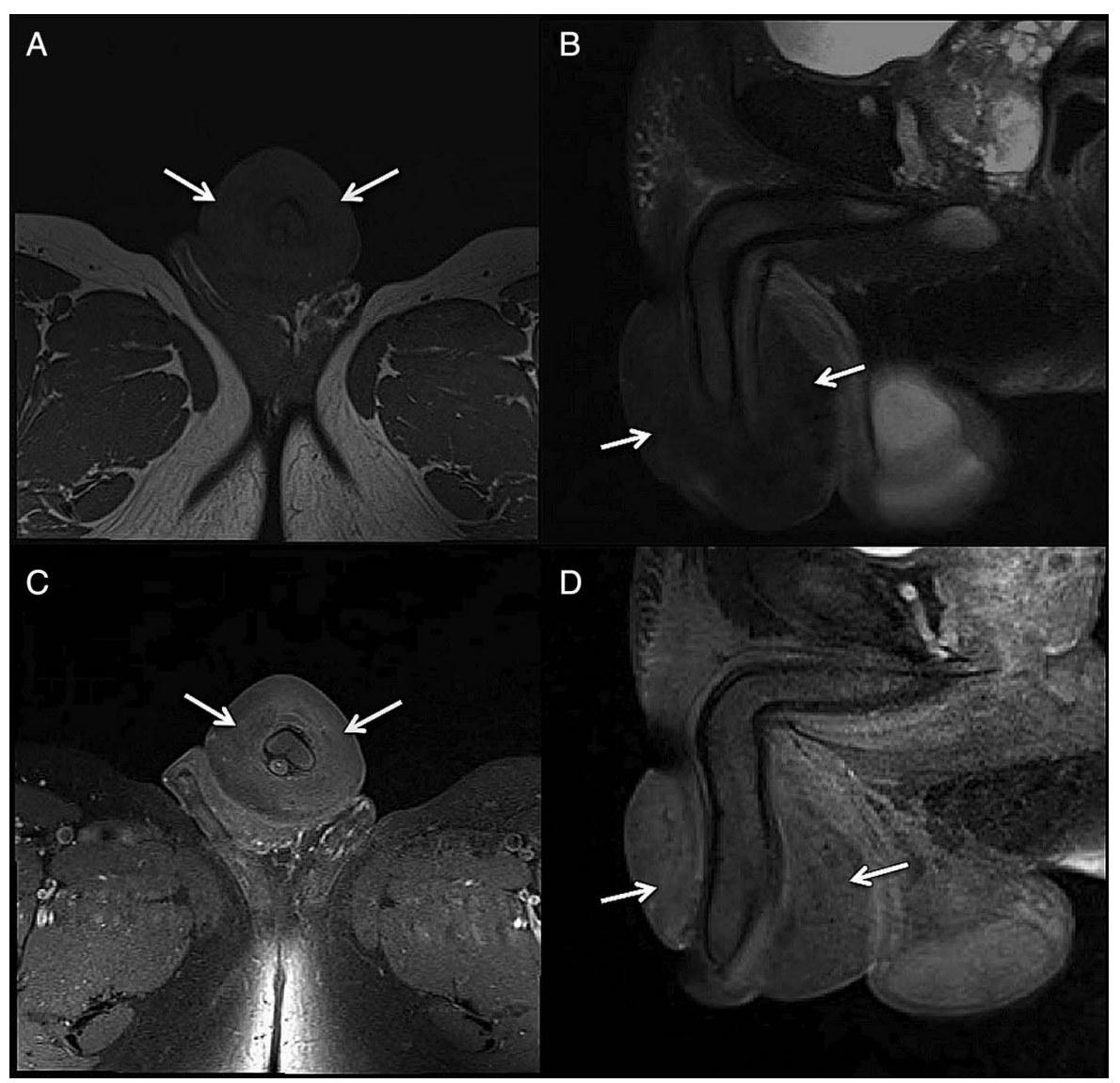

To cite: Majedah $S$, Hanafiah M, Awang MK. BMJ Case Rep Published online: [please include Day Month Year] doi:10.1136/ bcr-2014-205448

Figure $1 \mathrm{MRI}$ of the penis on (A) axial T1-weighted (T1W), (B) sagittal T2W, (C) axial T1W postgadolinium and (D) sagittal T1W postgadolinium images showing circumferential and diffuse thickening of the space between the Buck's fascia and the overlying skin (arrows). It demonstrates hyposignal on T1W and T2W sequences and heterogeneous enhancement in postgadolinium images. 
destructive consequences. The mainstay method in augmentation of penile size and contour is still surgery; although it is important to note that surgery itself is not without any risk of significant complications. ${ }^{3}$

\section{Learning points}

- Penile paraffin injection is usually offered and performed by untrained non-medical personnel. It usually leads to a destructive outcome owing to the lack of human body enzymes to metabolise interstitial exogenous oils and subsequent foreign body reaction.

- Paraffinoma consists of granulomatous foreign body reaction and surrounding soft tissue fibrosis, which may show low signal in T1-weighted (T1W) and T2W images in the chronic phase. Recent injection normally demonstrates high signal in T1W due to the short T1 relaxation time of mineral oil.

- Although paraffinoma is not common, clinicians need to be aware of this rare entity.

- Surgery is the main method for augmentation of penile size and contour.
Competing interests None.

Patient consent Obtained.

Provenance and peer review Not commissioned; externally peer reviewed.

\section{REFERENCES}

1 Sharif $F$, Crushell E, O'Driscoll $K$, et al. Liquid paraffin: a reappraisal of its role in the treatment of constipation. Arch Dis Child 2001;85:121-4.

2 Picozzi SCM, Carmignani L. Paraffinoma of the penis. Int J Emerg Med 2010;3:507-8.

3 Dillon $B E$, Chama NB, Honig SC. Penile size and penile enlargement surgery: a review. Int I Impot Res 2008;20:519-29.

Copyright 2014 BMJ Publishing Group. All rights reserved. For permission to reuse any of this content visit

http://group.bmj.com/group/rights-licensing/permissions.

BMJ Case Report Fellows may re-use this article for personal use and teaching without any further permission.

Become a Fellow of BMJ Case Reports today and you can:

- Submit as many cases as you like

- Enjoy fast sympathetic peer review and rapid publication of accepted articles

- Access all the published articles

- Re-use any of the published material for personal use and teaching without further permission

For information on Institutional Fellowships contact consortiasales@bmjgroup.com

Visit casereports.bmj.com for more articles like this and to become a Fellow 